\title{
The Play of Daniel in the National Musical Culture
}

\author{
Oksana Evgenevna Sheludyakova ${ }^{1, *}$
}

\author{
${ }^{1}$ Music Theory at the Urals Mussorgsky State Conservatoire, Ekaterinburg, Russian Federation \\ *Corresponding author. Email: k046421@yandex.ru
}

\begin{abstract}
The article is devoted to the consideration of the processes of biblical story implementation ("Play of Daniel") in the Old Russian culture and domestic works of the new time. The process of secularization was analyzed: from the church ceremony the Play moved first to the theater stage, and then to the fairgrounds, and in the early twentieth century was resumed in the concert hall. His liturgical side disappeared - prayers, liturgical hymns, the accent shifts to a dramatic and then comic performance, already in the play by Polotsky P. Only in the composition of the Kastalsky he once again took part in the performance as a church reader. The conclusion was made about a sharp reduction in its musical component - from "dewy poems" of considerable length, to brief "games" in the play by Simeon Polotsky and in skomorokh fun. Only at the beginning of the twentieth century, thanks to the "historical restoration" of Kastalsky A.D. a new, mostly musical version of the Play appeared.
\end{abstract}

Keywords: "Play of Daniel", Old Russian rite, Old Russian singing tradition, musical restoration of

Kastalsky. A

\section{INTRODUCTION}

In the liturgical tradition of Ancient Russia there were special rites, which are not preserved in church practice nowadays - the "Donkey walk" the "Healthy bowl" and, perhaps, the brightest of the rites - the "Play of Daniel". This church ceremony plays a special role in the culture of Ancient Russia as a unique rite that occupies an intermediate place between purely liturgical and secular. The rites in it concentrated the most complex samples of divine service singing and, at the same time, the elements of the future national theatre were born.

The Old Russian rite "Play of Daniel" repeatedly attracted the attention of musicians-performers, composers, artists: as an example, let us name the painting by Roerich N. "Play of Daniel" (1905), the choric play of A.Kastalsky ("Play of Daniel". For choir and bass solo. Ancient Church Rite", 1909), reconstruction of a fragment of the Play in the film by S. Eisenstein "Ivan the Terrible"1.

\section{OLD RUSSIAN DIVINE SERVICE}

The earliest written data on fulfillment of a rite in Russia concern Novgorod church culture, they remained in the account book for 1548 . According to

English composer Benjamin Britten also showed interest in this story, but the source of inspiration was not the Old Russian rite, but stained glass windows on the biblical themes of Chartres Cathedral. one version, this amazing Play appeared in church life thanks to an outstanding bishop - St. Macarius, Metropolitan of Moscow and All Russia (1482-1563). However, there is a different point of view: Church archaeologist Dmitrievsky A. assumed that in Russia the Play was known already at the end of XIV century: in the Old Russian legend "Walks of Ignatius Smolnyanin" ${ }^{2}$. The last evidence of the Play in the expenses books dates back to 1645 . Thus, the existence of the Playin the 16th-17th centuries is documented, but there are suggestions of an earlier emergence of the rite based on the Byzantine, and possibly Western European traditions.

The "Play of Daniel" is based on the biblical narrative in Chapter Three of the Book of Daniel. After three years of education and training at the court, Daniel and three young men ${ }^{3}$ began serving at the court of Nebuchadnezzar.

Ananias, Misael, and Azaria, together with Daniel, were chosen to serve among the noble Jews. The book of the prophet describes an episode in which Nebuchadnezzar conceived to make a solemn worship of a pagan deity by ordering the construction of a golden calf-idol in the field of Deir. All royal officials

The author of "The Walks" visited Constantinople in 1389. 1405. The Russian traveler describes church customs in great detail, mentioning, among other things, the "furnace of Shadrach, Meshach, and Abednego".

In the book, each of the Babylonian children had paired names: Anania (Sedrach), Misael (Misah) and Azariah (Abedenago). 
were obliged to participate in the rite. Under the fear of burning in a hot furnace everyone had to bow to the golden idol (Dan 3:1-11).

However, the children of Babylon broke the order and openly confessed their faith in the true God, refusing to serve the local gods and worshiping the golden statue. By order of Nebuchadnezzar, they were bound and thrown into a hot furnace (Dan 3: 12-23). The fire did no harm to them - the children were saved by the angel who descended into the furnace. The unbound and intact children - Ananias, Azariah and Mishael - sang a song to the Lord among the fire (Dan 3: 91-92). After seeing the miracle, Nebuchadnezzar blessed the God of Sedrach, Misach, and Abedenago, forbade insulting God, and gave top administrative positions to the children (Dan 3. 95-97).

Originally, the memory of the miracle of the Babylonian children took place on the Sunday (or two Sundays) before Christmas. In the post iconoclastic epoch the memory of the holy children was fixed for a specific date of December 17.

Since the salvation of the children from the furnace was seen as a prototype of the Resurrection of Christ, the song of the Babylonian children became part of the Matins, one of the themes of which is known to be the glorification of Christ's resurrection. In almost all liturgical monuments of antiquity, the songs of the Babylonian children decorate the festive Matins, usually replacing the repentant Psalm 50. In the original sequence, Azariah's prayer and the first part of the song of the three children were sung with the chorus "Hallelujah" and the second part with the chorus "Give blessing".

With the development of hymnography, the choruses to the hymns of the Babylonian children in Orthodox tradition were replaced by irmoses and troparions of the seventh and eighth songs of the canon $^{4}$, usually containing numerous interpretations of the miracle that happened to the children in Babylon.

In ancient times, the rite was performed only once a year, shortly before the feast of Christmas, December 17, the old style. There is information that the "Play of Daniel" was performed in Novgorod, Moscow, Vologda, Ryazan, Rostov and, quite probably, in other cathedral cities during the Patriarchal or other bishop's divine service.

The rite was prepared for several days. The most important attributes of the performance were: a furnace

\footnotetext{
Later on, a close conceptual connection emerged between the hymn of the three children and the hymn of praise to the Mother of God "My soul exalts the Lord": both the hymn of the Mother of God and the 8th and 9th hymns of the canon in modern practice are invariably present even in truncated canons (two, three, and four songs) in all sequences of the divine year.
}

(i.e. a tower divided into two tiers), iron tubes and a bugle with charcoal, candles, palms, shawls (towels), the attire of the Play's participants, a three-dimensional image of the Angel, which at the right moment rose and fell with the help of a rope, sliding from the altar and thrown over the block. To ignite the flame, purple lythrum - an easily illuminating grass - was used.

Three young men, two chaldeans (servants of the tsar), a young teacher and a choir directly participated in the Play. The church clergy helped the performers, and the bishops present blessed the performers before and at critical times. The roles of the teenagers were performed by the young people with the best voices in the choir. Irmoses and stikheres sounded many times during the celebration. An adolescent teacher (tired man) helped to dress up the boys ${ }^{5}$, to light their candles, accompanied them to the furnace. The Chaldeans were probably sung by adult singers ${ }^{6}$.

The "Play of Daniel" many times attracted the attention of scientists of different specialties philologists (Veselovskiy A. [1], Morozov P. [2], Pekarskiy P. [3]), church archaeographers (Nikolsky K. [4], Dmitrievsky A. [5]), musicologists ( Metallov V. [6], Findeisen N.[7], Keldysh Yu. [8], Velimirovich M. [9]). However, it was only in the last two decades that a multifaceted analysis of the rite "Play of Daniel" and the chants that it includes was carried out. In S. Kravchenko's article [10] and in N. Terentyeva's dissertation [11] the full text of the hymns was published. The origin of the hymns was analyzed, and the full rite was reconstructed on the basis of comparison of text versions of the Play among themselves, as well as texts contained in the Episcopal service book and with the biblical source.

In the Old Russian rite "Play of Daniel" several important features were formed:

- The ceremony was positioned as a church one, held in the cathedral church during the divine service on a day defined by the church charter.

- The ceremony was led by the highest church hierarchs - Patriarch or Metropolitan.

- The highest secular authorities - the tsar or prince with his family - took part in the

5 Leather hats, or crowns, with cast copper crosses were worn on the children's heads. The vestment consisted of a stikharionsewn from a thin expensive canvas, decorated with velvet patterned arms and sleeves. Sources, i.e. stripes of a colour other than the garment itself, fell to the hem and were made of dye or ribbon.

6 Hats of the Chaldeans were called sholems, or turiks. The ancient wreaths and Chaldean turiks were swollen with hare or ermine fur and coated with gold. Chaldean dresses were called skirts or yups and were sewn from a red-baggy cloth. The palms that the Chaldeans held were supposedly carved from wood and gold plated in paint. 
ceremony as parishioners and, at the same time, as spectators.

- The rite was based on the most modern and developed singing style by the time of its performance, the best singers of the time took part in its performance, the best didascals participated in the preparation.

- The rite included some small secular elements in addition to purely ecclesiastical ones: in the actions of the Chaldeans there were some signs of skomorokh culture (replicas of a simple nature $)^{7}$.

- The dramaturgical component played a major role, and actions not typical of divine services were also used (e.g. the burning of purple lythrum or the Chaldeans' literary dialogues).

- Over the years, neither the words of the chants, nor literary texts, nor rite acts were changed, and the rite was gradually canonized.

\section{PLAY FOR THE COURT THEATRE OF SiMEON POLOTSKY}

The dramatic work "About the Tsar Navhodonosor, on the gold idol and the three children, in the furnace not burned" is the first Russian poetic drama created for the court theater of Tsar Alexei Mikhailovich. One of her story sources was the rite of the "Play of Daniel" in the Moscow version, which is recorded in the Episcopal service book of the Assumption Cathedral. Unlike the Novgorod rite, its dramatic scenario is significantly reduced and is a liturgical oratorio. The play was written and presented in the Christmas-tide in 16731674, becoming a ceremonial Christmas gift to the Russian sole ruler. In the genre of the play gravitates towards the scientific tragedy and meets its normative elements.

Simeon Polotsky owns at least two surviving plays: "About the Tsar Navhodonosor, on the gold idol and the three children, in the furnace not burned" and the comedy "The parable of the prodigal son ". However, Polotsky also created a large number of so-called

\footnotetext{
7 The first Chaldean. Brother!

The second Chaldean. What's the matter?

The first Chaldean. Are they the tsar's children?

The second Chaldean. Sure they are. command?

The first Chaldean. Have the disobeyed the Tsar's

The second Chaldean. They're not listening.

The first Chaldean. And they don't worship the gold idol,

righ?

The second Chaldean. They don't.

The first Chaldean. Let us send them to the furnace then?

The second Chaldean. Let them burn.
}

"dialogues" and "recitations", which, although they cannot be attributed to us as truly dramatic works (based on the criteria currently in place), nevertheless, in their form they are close to the theatrical drama.

An excellent connoisseur of the rite side of Christianity, he chose for his first drama the widely known in Orthodox liturgical practice "Play of Daniel", usually played on Christmas Eve. The Biblical tsar was painted in the play by Simeon Polotsky by a ruthless tyrant. His deeply wicked deeds and thoughts were opposed by the wise reign of the "most pious and exalted", "God-given" Alexei Mikhailovich, who establishes in his kingdom laws that correspond to those of God. He is addressed by the author in the "Foreword" (prologue) of his play ${ }^{8}$ : the virtues of the tsar are praised, and in contrast, they make an indication of unbelief and pride of Nebuchadnezzar, who declared himself a god and ordered to throw three children in the furnace for disobedience.

The comedy "About Tsar Nebuchadnezzar" is not divided into acts. After the "Foreword", which consists of an appeal to Tsar Alexei Mikhailovich, it is announced that this event will be a "comedy" in front of the tsar and the boyars ${ }^{9}$; the theatrical story begins involving many actors and statists.

Nebuchadnezzar, with his boyars, six servants and six armed warriors, enters the stage, sits on the royal throne praising his own power, calls himself the god of gods and orders the treasurer to issue gold for the manufacture of his statue, which, according to his command, should be worshiped by all peoples. The treasurer leaves to execute the Tsar's order, and the Tsar commands another boyar, Zardan, to build a furnace near the statue, in which anyone who does not want to worship the Tsar's image should be thrown. There are two curtains in the back of the stage.

Then one veil rises, a statue is shown, another veil rises, the stove is shown. Boyar Amir reports to the Tsar that all the people are already standing in the field Deira. The tsar appeals to the "voices" and orders to play. They begin to "trumpet and squeal." All men fall down, but three men do not bow; Amir commands them to be caught. Then the play goes according to the Daniel's recount. The furious tsar demands worship,

8 God in Trinity, you are the one who is worshiping. and the proper bow is humble,

Tsar Navhodonosor living in sings, holding a scepter in the right hand.

9 Let's share the truth in a comedy manner, And reveal it as it is

We worship your and all the heavenly host You've been serving well ot the princes and boyars. Comforting your heart, you'll see, And keep us in your mercy. 
and the children do not obey, they are thrown into the furnace. An angel appears, the children sing their song with words like in the Bible. The tsar, seeing such a miracle, repents, worships the true God and orders to honor the survived children.

The comedy ends with Epilogue, wishing a peaceful reign to the tsar as well as victory, long life and heavenly crown.

There are not so many musical fragments in the performance, but they play an important semantic formforming function.

"Playing" on various musical instruments can be heard the first time since "The Foreword". Then, while the statue and the oven for the next episode are being prepared, the tsar orders the musicians to be called in order to fill in the pause with something. In the scene with the worship of the statue there are trumpets and pipes, the tsar commands to "blow, play instruments and play the pipes", the musicians are prescribed to "play and blow the pipes". Then there are readings from the book of prophet Daniel (most likely lines corresponding to the plot) and singing of the children related to the text of the same biblical book. At the end of the play, the author leaves room for the so-called "jubilations" ("jubilations shall take place"), as well as many years, or "playing" on musical instruments.

The musical side of the work is not specified by reference to specific compositions. According to most scientists, the production could use various opuses performed on musical instruments and dramas corresponding to the plot by nature and instrumental composition.

Even in the case of the book of prophet Daniel some initial words are given, but neither the length of singing nor the singing style are defined. This is partly due to the variability of performance depending on the composition of participants and spectators. The lack of instruction is partially determined by the participation of professional church singers in the production. It is no accident that Mike L.N. [12] links the plot of the play "About Tsar Navhodonosor..." with the liturgical rite of the "Play of Daniel". He rightly points to the belonging of the participants of the theatrical church ceremony three children and two Chaldeans - to the temple ministers, the relationship of characters with the bishop's singers.

Thus, the analysis of Simeon Polotsky's play allows us to draw the following conclusions:

- The play retains the plot of the "Play of Daniel", but it is complemented by the Foreword and the Epilogue, in which the secular state power is praised.
- In the foreground comes a theatrical, dramatized side (it is not by chance that literary scholars refer to the play to the genre of drama). Music begins to play a subordinate role.

- In the ratio of secular and ecclesiastical sides, secular, hymns and ecclesiastical readings are used only in one episode. The church authorities were not present at the performance.

- The play is of a moral nature, but the entertainment element becomes strong enough.

Later on, the plot moved to the fairgrounds, performed by artists of open-air stages by skomorokhs. It has not yet been possible to find an accurate and complete record of such a representation. It is only known that the main characters were Chaldeans, the role of the children became static, the number of their comments was reduced to a minimum, and the angel as a character replaced the image in full height. The role of music was also limited to playing melodies using skomorokhs instruments at the time of the change of scenery.

\section{MUSiCAL RESTORATION OF ALEXANDER KASTALSKY}

The reason why Alexander Kastalsky turned to the Old Russian rite was his deep interest in the unusual and previously unknown genre of musical and historical restorations. They combined the composer's archaeological inclinations and passion for experiment, his careful treatment of ancient chanting and his desire to revive musical history. The first attempt, the cycle "Samples of church singing in Russia of the XV-XVII centuries", was followed by others, despite the composer's own vocation not to start any more archaeological ideas. They were associated not only with Russian folklore, but also with folk music from other world cultures.

Already while writing the first monumental cycle, Kastalsky A.D. was interested in the rite "Play of Daniel", for the creation of which he again, as well as for the previous work, did a great research work: collected and studied scientific literature, found the singing manuscripts, which contained descriptions of the Play, tried to decipher the unmarked hooked notation. In 1907 the composer completed the "Play of Daniel" for the chorus and soloists on the basis of the medieval liturgical Play of the same name about three Babylonian youths (M.P. Jurgenson's publishing house, 1909).

The work was premiered on March 18, 1907. In April 1909 in the hall of the Synodal College was a theatrical performance based on the Kastalsky's work. New parade costumes were sewn for the singers based on Vasnetsov's sketches. The concert was attended by 
the Grand Duchess Righteous Martyr Elisabeth Romanova, a patroness and admirer of the Synodal Choir.

It was Kastalsky who became the ancestor and, at the same time, the "musical restorer" of a new genre - a musical play. He inherited from the Old Russian singers not only melody, themes, and spirit of creation, but also creative principles based on the inseparability of the constituent elements of the temple play, and determined by the tasks of divine service and the church calendar" [13].

The Kastalsky's work is intended for chorus and soloists, it clearly distinguishes the style of the Old Russian monody in the introduction ("On the field of prayer") and the actual style of Kastalsky - with a virtuoso harmonisation of songs close to everyday life ("Blessed is the Lord") against the background of the recitation of selected words of the Book of Daniel the Prophet. The work is divided into two parts, different in tempo, intonation material and tonal plan, which fully corresponds to the incarnate plot - the appearance of an angel of the Lord becomes a boundary, after which the children's request is replaced by a praise of the power of God.

In the composition of Kastalsky many important features of the Old Russian rite are resurrected:

The premiere took place in the performance of the Synodal singers, in the Diocesan House, at a meeting of the Commission for the Study of Ancient Church Monuments of Moscow and the Moscow Diocese ${ }^{10}$. Thus, the premiere was almost a significant event for the Church.

10 As Moskovskie vedomosti reported (1907. 20 March/April 2. No.65. Tuesday. P. 4) "On March 18, Sunday, at 8 pm, in the Great Hall of the Diocesan House an "open session" of the Commission for the Study of the Monuments of Church Antiquities of Moscow and the Moscow Diocese took place, which was honored by the presence of their Imperial Highnesses the Grand Duke Dimitri Pavlovich and Grand Duchess Maria Pavlovna, the Moscow Governor. Junkovsky V.F., Governor-General Hershelman S.K., former Minister of Public Education Glazov V.G> ... (...) Next came the "Play of Daniel" performed by the full chorus and individual soloists of the synodal singers orchistrated by the famous talented composer Kastalsky A. D., who, on the basis of ancient hooked notes relating to the "Play of Daniel", composed very beautiful, charming music ... The performance of the "Play of Daniel" was inimitable. Listening to delightful church music, we were mentally transferred to that interesting epoch, when the rite was performed in the Assumption Cathedral in Moscow and in the Cathedral of St. Sophia - in Novgorod. The strength and power of the synodal choir (up to 100 people), of course, fully corresponded to the patriarchal Moscow church clergy. The singing was accompanied by a reading of the essay by Professor of the conservatory priest Metallov V.M., which helped understand the Play and music. With the help of the magic lantern many light paintings were reproduced from the miniatures of XI-XVII centuries and from the last painting by Roerich N.K. - "Play of Daniel", which was at the newly closed exhibition of the Union of Russian Artists" [14].
In ancient times the rite was headed by church hierarchs - in the XX century (April 10 and 12, 1909) the sacred text was read by the vicar of the Moscow diocese Bishop Dmitrov Trifon (Turkestan).

In 1909, Elizabeth Romanova, sister of the Empress, Grand Duchess, took part in the ceremony as a spectator, as a representative of the highest secular power.

Just as the Old Russian ritual was based on the most modern and developed singing style at the time, Kastalsky's work is replete with complex texture techniques, vivid modulation shifts and the most complex rhythmic organization. At the same time, many signs of the church tradition are carefully embodied - the sacred text, canon reading, the tune of the theme "On the field of the prayer", which could be used in the Old Russian rite, is quoted.

The Old Russian rite included small secular elements besides purely church ones. In Alexander Kastalsky's work, church and secular origins are deeply interacting and interpenetrating, and none of them is the main one.

A big role in ancient Russia was played by the dramaturgical component, some ritual actions. In the musical restoration of Kastalsky there appeared "a small performance, developing on an uncomplicated plot, and containing all the attributes of the stage action in the primitive form, which is inherent in the medieval folk theater [13].

As Terentyeva P. points out, in comparison with the Divine Service rite, the author's work is very brief. So, out of nine dewy verses there is one left - "On the field of prayer...", the singing of the children "And endeavour..." as if merges with the Seventh song, the number of verses of the Bible song is reduced. Different stylistic strata are combined - Znamenny chant, Obikhod chant, psalmody.

\section{CONCLUSION}

The study provides the following general conclusions.

There's been a noticeable secularization process. From the church ceremony the action moved first to the theater stage, and then to the fairgrounds, and in the early twentieth century was resumed in the concert hall. The ritual ceased to be a church ritual performed in the cathedral temple in the presence of the church hierarchy.

The center of the Old Russian rite were the blessings of the Metropolitan or Patriarch, the singing of clergy and the reading of priests. In spite of the fact that the Play was built into the non-divine services, it was the temple rite that prevailed. Gradually the 
liturgical side of the rite disappeared completely - the prayers were not included, the hymns of the service became episodic. Correspondingly, the liturgical text of the book of Prophet Daniel was also shortened, which in Simeon Polotsky's drama was already given in fragments, and was reproduced depending on the intention of the director. The emphasis in Polotsky's play shifts to the dramatic, and then, in the skomorokh culture, to a comic performance. Only in the Kastalsky's composition the holy text sounded again in full, and the bishop took part in the performance, though only as a church reader.

Changes were made in the plot of the Play - the main characters were gradually becoming not teenagers, but Chaldeans. It was their remarks that became more and more developed and gradually broke the original plot balance. New characters appear - the wicked king himself, his advisers, and so on. On the contrary, an angel from one of the main characters, a spiritual messenger singing divine songs, turns into an iconographic image, and then a symbolic one - the character depicted in the picture.

The musical component of the rite was drastically reduced - almost two hours of singing "dewy poems" and choruses of considerable length were replaced by relatively brief "melodies" in the play by Simeon Polotsky and in skomorokh fun. Only at the beginning of the twentieth century, thanks to the "historical restoration" of Kastalsky A.D., a new, mostly musical version of the Play appeared, with a small theatricalization and participation of the clergy. However, it is also inferior in duration and scale to the Old Russian prototype.

In recent decades there has been renewed interest in the culture of Ancient Russia, including this most interesting ritual. Researchers Kravchenko S.[10] and Terent'yeva N.[11], who provided note materials and data of scientific research to the ensemble "Sirin", which carried out historical reconstruction of the rite, made a significant contribution to this process. This gives hope that new compositional opuses inspired by the "Old Russian miracle" will also appear.

\section{References}

[1] A.N. Veselovsky, Old Theatre in Europe. Historical Essays, M., $1870,410 \mathrm{p}$.

[2] P.O. Morozov, History of dramatic literature and theatre. V.1. St. Petersburg, 1903.210 p.

[3] P. Pekarsky, Introduction to the History of Enlightenment in Russia of the XVIII century. St. Petersburg, 1862. 578 p.

[4] K.T. Nikolsky, On the services of the Russian Church, which were in the previous printed liturgical books. St. Petersburg, 1885 .

[5] A.A. Dmitrievsky, The Play of Daniel Rite. Historical and archeological sketch//separate imprint from the journal
"Byzantine Vremennik", vol.1, 3 and 4 ed. St. Petersburg, 1895.48 p.

[6] V.M. Metallov, In memory of the Play of Daniel// Svetilnik. 1914. No.4. P.1-6.

[7] N.F. Findeisen, Essays on the history of music in Russia from ancient times to the end of XVIII century. V.1. M., 1929.

[8] Yu.V. Keldysh, Religious Actions//History of Russian Music. V. I. M., 1983.P. 152-160.

[9] M. Velimirovic, Liturgical Drama in Byzantium and Russia//Dumbarton Oaks Papers, No.16, Washington, D. P, 1962. P. 351-385.

[10] S.P. Kravchenko, "The Play of Daniel" New discoveries//Musica Antiqua Europae Orientalis. Vol. 5 No.2. Bydgoszcz, 1987. P. 1-12.

[11] P. Terentyeva, The "Play of Daniel". M., Sports and Culture. 2015, 296 p.

[12] L.N. Miakov, Essays on the history of Russian literature of the XVII and XVIII centuries - St. Petersburg, 1889.

[13] S.G. Zvereva, Alexander Kastalsky: Ideas, creativity, fate... M., 1999. 240 p., P. 96

[14] Moskovskie vedomosti (1907. 20 March/April 2. No.65. Tuesday. P. 4) 